\title{
Effect of mānuka (Leptospermum scoparium) on nitrogen and Escherichia coli reductions in soils: a field experiment
}

\author{
Sky Halford • María J. Gutiérrez-Ginés $\mathbb{D}$. \\ Andrew Rees · Izzie Alderton · Kolja Schaller • \\ Rawiri Smith · Jacqui Horswell
}

Received: 8 April 2021 / Accepted: 1 June 2021 / Published online: 9 June 2021

(C) The Author(s) 2021

\begin{abstract}
Purpose Planting strategies can be effective mechanisms to reduce diffuse pollution from agricultural catchments reaching water bodies. Plants with antimicrobial properties such as mānuka (Leptospermum scoparium) demonstrated in controlled conditions the ability to inhibit nitrification and growth of pathogens in soils. This potential in a real on-farm setting was still to be investigated.

Methods In a stock-excluded riparian area, planted with mānuka on a dry stock farm, synthetic excrement
\end{abstract}

Responsible Editor: Zucong Cai.

S. Halford · I. Alderton

The Institute of Environmental Science and Research, Porirua, New Zealand

e-mail: skyhalford@hotmail.co.nz

S. Halford · A. Rees

School of Geography, Environment and Earth Science,

Victoria University of Wellington, Wellington,

New Zealand

M. J. Gutiérrez-Ginés $(\bowtie) \cdot$ J. Horswell

The Institute of Environmental Science and Research, Christchurch, New Zealand

e-mail: maria.gines@esr.cri.nz

K. Schaller

Greater Wellington Regional Council, Wellington,

New Zealand

R. Smith

Ngāti Kahungunu ki Wairarapa, Masterton, New Zealand patches high in urea (950 kg N ha ${ }^{-1}$ equiv.) and Escherichia coli $\left(7.9 \times 10^{9} \mathrm{cfu}^{\text {plant }}{ }^{-1}\right)$ underneath mānuka saplings and pasture were applied. Soil was sampled at three depths over 21 days after the excrement application and analysed for total $\mathrm{C}$ and $\mathrm{N}$, inorganic N, pH, soil moisture and E. coli.

Results There was no significant difference between the pasture and mānuka for total $\mathrm{C}$ and $\mathrm{N}, \mathrm{C}: \mathrm{N}$ ratio, and soil moisture. E. coli was only different between both at 20-30 cm deep. $\mathrm{NO}_{3}{ }^{-}-\mathrm{N}$ and $\mathrm{NH}_{4}{ }^{+}-\mathrm{N}$ concentrations were significantly lower under mānuka compared to pasture for the upper two soil depths $\left(\mathrm{NO}_{3}{ }^{-}-\mathrm{N}: 109 \mathrm{mg} \mathrm{kg}^{-1}\right.$ vs $205 \mathrm{mg} \mathrm{kg}^{-1}$ in the topsoil).

Conclusions The results of this study indicate that mānuka may inhibit urease activity and nitrification and could reduce on-farm nitrate leaching, while also highlighting that field conditions make quantifying such phenomenon more complex.

Keywords Leptospermum scoparium $\cdot$ Biological nitrification inhibition $\cdot$ Escherichia coli $\cdot$ Riparian planting $\cdot$ Shelter belts

\section{Introduction}

As one of New Zealand's largest export markets, pastoral agriculture is a vital part of the national economy and accounts for $40 \%$ of total land cover (Ministry for the Environment and StatsNZ 2018). 
However, agricultural intensification to meet export demands has come largely at the expense of wellfunctioning ecosystems and has resulted in declining freshwater quality across the country (Dymond et al. 2013; Julian et al. 2017; MacLeod and Moller 2006). Increased stocking rates and associated animal excreta as well as and nitrogenous fertilisers are leading causes of declining freshwater quality (Julian et al. 2017; Parfitt et al. 2006). Faecal contamination from overstocking, direct stock access to waterways, and farm effluent pose a health risk and limits New Zealanders' capacity to enjoy waterbased recreational activities (Collins et al. 2007; Houlbrooke et al. 2004).

The New Zealand setting is just one example of a worldwide crisis regarding the impact of agriculture intensification on water quality. Globally, over $87 \%$ of the $\mathrm{N}$ agricultural inputs are not used by plants or livestock, and forms the so-called $\mathrm{N}$ surplus (Galloway et al. 2003). Depending on the agricultural system, over $80 \%$ of the soil $\mathrm{N}$ surplus can be lost via leaching (Billen et al. 2013), which will consequently affect waterbodies. According to Billen et al. (2013), the $84 \%$ of the anthropogenic $\mathrm{N}$ is accumulated in basins that occupy only $43 \%$ of the global continental area. These "hot-spot" basins are located in Europe, North America, India, China, New Zealand, and small coastal basins in South America (Billen et al. 2013). According to Bain et al. (2014), 1.8 billion people globally are exposed to faecal contaminated drinking water, and most of faecal contaminated drinking water occurs in rural areas. In US, about 480,000 km of rivers and shorelines and 2 million ha of lakes are impaired by pathogenic contamination (Pandey et al. 2014).

Planting of riparian areas and creation of shelterbelts are effective mechanisms to minimise negative environmental impacts in agricultural regions (Billen et al. 2013). Riparian planting strategies have been shown to reduce nutrient runoff, microbial contamination, and erosion and sedimentation in small streams (McKergow et al. 2016). Shelterbelts have been shown to limit nitrate movement (Ryszkowski and Kędziora 2007) and reduce Escherichia coli runoff (McDowell et al. 2006). If riparian plantings or shelterbelts comprise native vegetation, there is also the potential to increase biodiversity in areas that are usually depauperate of it, and there is increasing demand and necessity for enhancing native biodiversity on farms (Lee et al. 2008).

Utilisation of mānuka (Leptospermum scoparium) in planting strategies is being investigated to further reduce negative environmental impacts. Mānuka is an indigenous pioneer shrub with ubiquitous presence across New Zealand (Stephens et al. 2005). It is wellknown to thrive in extreme environmental conditions, such as low fertility soil, and acts as a colonising species in successional forest development (Stephens et al. 2005). Antimicrobial properties in mānuka honey, oils, and leaves has made the plant culturally significant to Māori for its use in rongoā (traditional Māori medicine) (Williams 1996) and also within modern medical practice with mānuka honey products incorporated into wound treatment and personal care products (Stephens et al. 2005).

The antimicrobial properties observed in essential oil products are postulated to have similar effects on pathogen survival within the root networks. Prosser et al. (2014) concluded that mānuka leaf, oil, and root extracts all either significantly reduced or inhibited growth of five bacterial species (both gram-positive and gram-negative), whereas ryegrass supported bacterial growth in all but one species. Similarly, Prosser et al. (2016) found in a subsequent study that potted mānuka significantly reduced $E$. coli counts, with a $90 \%$ reduction in eight days (compared to 93 days for ryegrass). Mishra (2018) also found mānuka root extracts showed inhibition of $E$. coli growth; however, the root system encouraged preferential flow and leaching down the soil profile at high irrigation schemes $\left(14 \mathrm{~mm} \mathrm{~d}^{-1}\right)$.

Comparable properties were observed with the effects of mānuka on nitrogen cycling and could be useful in biological nitrification inhibition (BNI), whereby traits of a natural ecosystem can control the nitrification process (Subbarao et al. 2006). Downward (2013) demonstrated that mānuka extracts inhibited nitrifying bacteria activity of Nitrosospira sp. cultures while pasture extracts did not. Likewise, a lysimeter study by Esperschuetz et al. (2017) found that following successive urea applications, mānuka significantly reduced nitrate leaching $\left(2 \mathrm{~kg} \mathrm{ha}^{-1}\right)$ compared to pine $\left(53 \mathrm{~kg} \mathrm{ha}^{-1}\right)$. Higher concentrations of ammonium under mānuka suggested inhibition of nitrification enzymes as the leading cause (Esperschuetz et al. 2017). In addition, reduced cumulative nitrous oxide emissions under mānuka compared to 
pine suggested inhibition of denitrification enzymes (Esperschuetz et al. 2017).

Use of mānuka in on-farm planting strategies has the potential to mitigate bacterial inputs from stock and reduced nitrate loading through BNI. However, to date these effects have been limited to laboratorybased studies, with a paucity of information on how the natural environment influences the response of mānuka to agricultural waste rich in nitrogen and bacteria pollution. In this work, we sought to address how these interactions occur in the natural riparian environment by testing the following hypotheses: (a) there is a difference in nitrogen speciation between mānuka and pasture, where there is less nitrate and more ammonium accumulation in soil under mānuka than under pasture, and (b) there is a faster reduction in E. coli counts with mānuka compared to pasture, and the reduction is impacted by preferential flow.

\section{Materials and methods}

\section{Study site}

The experiment was conducted in a newly planted mānuka riparian zone, situated on the western side of Lake Wairarapa, New Zealand $\left(-41.183182^{\circ}\right.$, $175.254344^{\circ}$ ) (Fig. 1). The riparian zone is a
Fig. 1 Map of the study site used in this experiment. Mānuka was planted in the pink area, with the fencedoff unplanted site in the blue areas. The upper map shows the site location in relation to the wider Lake Wairarapa landscape

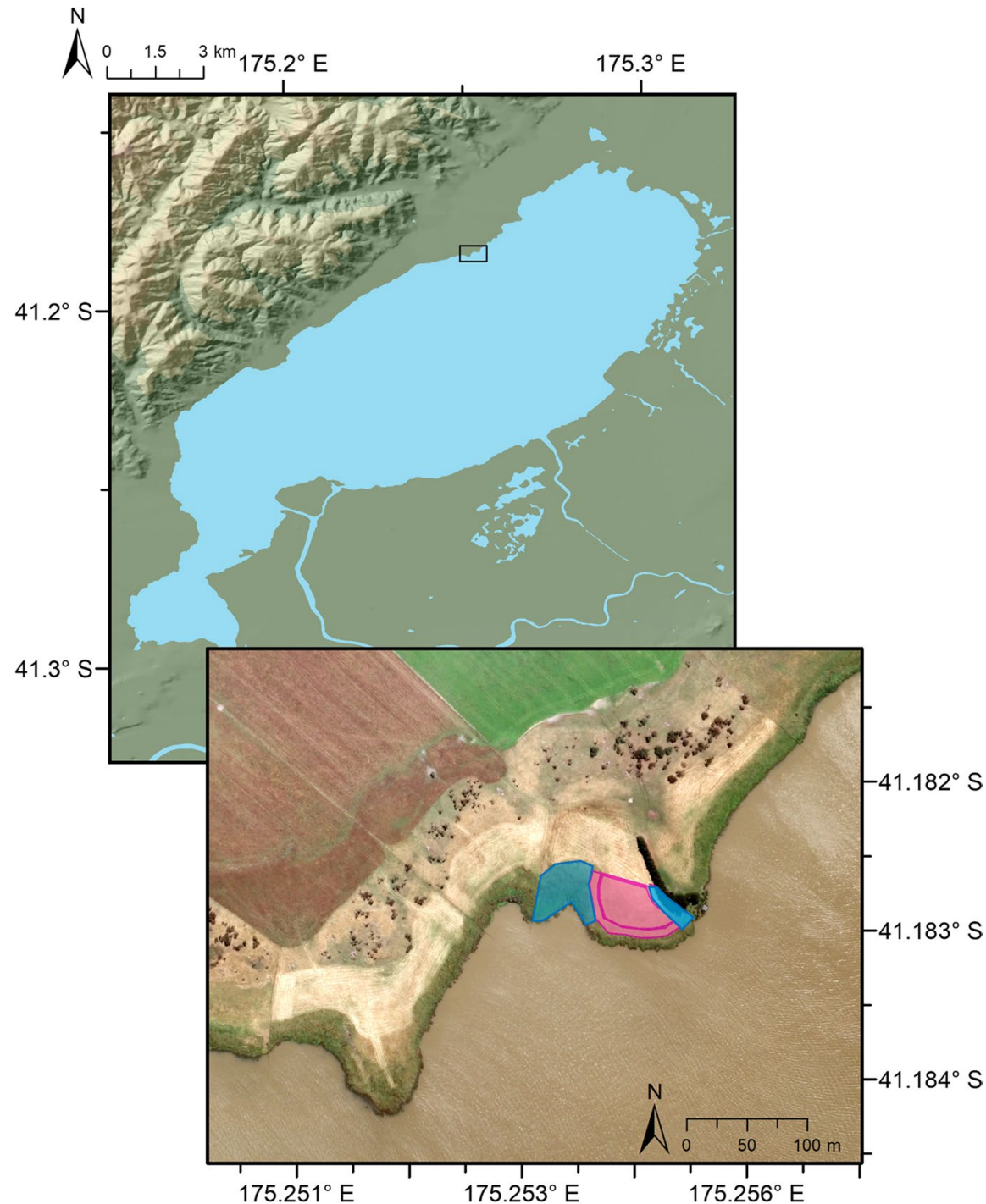


fenced-off band of variable width $(20 \mathrm{~m}-60 \mathrm{~m})$, which borders a sheep and beef farm that uses sulphur, phosphate, and nitrogen fertilisers. The area is relatively flat and slopes gently to the edge of the lake. Soils underlying the study site are Orthic Brown (LandcareResearch 2018). An area of approximately $2500 \mathrm{~m}^{2}$ was planted with c.a. 4300 mānuka at 1-m spacing. Within the fenced-off zone, and at both sides of the mannuka planted area, there are unplanted areas $\left(1800 \mathrm{~m}^{2}\right.$ and $\left.1010 \mathrm{~m}^{2}\right)$ with plant cover consisting mostly of Lolium perenne (pasture).

\section{Field experiment}

To test the hypotheses, a field experiment was completed between October and November 2018, exposing mānuka and pasture to a worst-case scenario of a "synthetic" excrement patch with high concentration of urea and E. coli. At the time of the experiment, mānuka saplings had grown for 14 months and were around $1 \mathrm{~m}$ tall.

Within the mānuka planted area, fifteen saplings of similar size were randomly selected for the experiment. A circle of $15-\mathrm{cm}$ radius (approximately $707 \mathrm{~cm}^{2}$ ) was marked out around each sapling for applying the "synthetic" excrement patch (Fig. 2a and c). Similarly, 15 random circles of the same size $\left(707 \mathrm{~cm}^{2}\right)$ were selected within the unplanted area to investigate the effect of pasture (Fig. $2 b$ and d). The mānuka and pasture circles were placed in the central area of their respective zones to avoid potential influence from the other areas, and from the farm paddock.

Synthetic urea $\left(\mathrm{CH}_{4} \mathrm{~N}_{2} \mathrm{O}\right)$ was applied at a rate to imitate cow urination to test the effects on nitrogen cycling. Average urine concentrations are typi-


event can range between 20 and $120 \mathrm{~g} \mathrm{~N} \mathrm{~m}^{-2}$ (Selbie et al. 2015). Therefore, $14.15 \mathrm{~g}$ of urea was added to $700 \mathrm{~mL}$ of distilled water, equating to $95 \mathrm{~g} \mathrm{~N} \mathrm{~m}^{-2}$. The $700 \mathrm{~mL}$ of diluted urea solutions were applied to each of the 30 marked areas (15 for each treatment).

Similarly, E. coli was applied at a rate to emulate a worst-case scenario of excrement with high numbers of $E$. coli. The $E$. coli strain used in this experiment was isolated from dairy shed effluent to represent a strain likely to be found in farm settings. Here, $100 \mu \mathrm{L}$ of dairy shed effluent were plated into $E$. coli selective agar (Brilliance ${ }^{\mathrm{TM}}$ ) and grown overnight at $34{ }^{\circ} \mathrm{C}$. Ten E. coli colonies were taken from the plate and grown together in $30 \mathrm{~mL}$ Luria broth at $34{ }^{\circ} \mathrm{C}$ for $24 \mathrm{~h}$. The broth was then centrifuged at $2000 \mathrm{rpm}$ for $1 \mathrm{~h}$. The resulting pellet was washed twice with Ringer's solution to form a seed stock and stored at


Fig. 2 Example sites of mānuka and pasture treatments following sampling: (a) mānuka prior to sampling, (b) pasture prior to sampling, (c) mānuka after sampling, (d) pasture after sampling 
$4{ }^{\circ} \mathrm{C}$ until it was used in the experiment within two weeks. The $E$. coli in the seed stock was enumerated by plating serial dilutions and the colony forming units (cfu) were used to calculate the numbers to be applied to the experiment. Given the median E. coli numbers in cow pats $\left(6 \times 10^{6} \mathrm{cfu} \mathrm{g}^{-1}\right)$ (Moriarty et al. 2008), and an average excrement weight for bovine cattle of $2 \mathrm{~kg}$ (Kormanovskii et al. 2017; Scheile et al. 2018), E. coli was added to the experiment at a rate of $7.2 \times 10^{9} \mathrm{cfu}$ per ring in each of the 30 rings. E. coli from the seed stock was resuspended in Ringer's solution and diluted to the required numbers to be applied to the field experiment. The E. coli cfu in the final solution were enumerated by plating serial dilutions to confirm that the added $E$. coli was the same than the calculated one.

Prior to application of urea and E. coli solutions, excessive grass growth around mānuka trees was cut back and the pasture in the unplanted area trimmed to $2 \mathrm{~cm}$ to allow solutions to reach root networks. The solutions were applied slowly over a period of three hours to allow percolation and avoid runoff out of the marked areas.

A baseline sampling was performed one month before the experiment started. After the "excrement" application, soil was sampled after 1 day, 3 days, 7 days, 14 days, and 21 days. At each of these time points, three mannuka and three pasture areas (out of the 15 treated with the "excrement") were randomly selected and sampled. Soil samples were collected from both treatments at $0-10 \mathrm{~cm}, 10-20 \mathrm{~cm}$, and $20-30 \mathrm{~cm}$ using a soil probe. Soil samples were transported on ice to the laboratory, kept at $4{ }^{\circ} \mathrm{C}$ overnight and processed the following day. This length of the experiment (21 days) was selected to be comparable with previous research by Esperschuetz et al. (2017), who found a quick response in ammonia oxidation and $\mathrm{NO}_{2}$ fluxes in soil in the first 18 days after urea application in their lysimeters, with a slower change until day 21. Similarly, Prosser et al. (2016) reported a significant reduction of $E$. coli under mānuka in a 7-day experiment, and Gutierrez-Gines et al. (2021) in a 21-day experiment.

Chemical and biological analysis

Fresh soil samples were sieved $(2 \mathrm{~mm})$ and analysed for soil moisture, inorganic nitrogen, and E. coli. $\mathrm{NH}_{4}{ }^{+}-\mathrm{N}$ and $\mathrm{NO}_{3}{ }^{-}-\mathrm{N}$ were extracted with $2 \mathrm{M} \mathrm{KCl}$
(Blakemore et al. 1987) and analysed by Flow Injection Analyser (Quikchem 8500). E. coli was enumerated using a 5-tube MPN procedure as described by Horswell et al. (2007). Enumeration was completed by comparing the results with a MPN table and calculated per gram of dry soil (Prosser et al. 2016). Soil moisture was determined after drying the samples at $104{ }^{\circ} \mathrm{C}$ for $48 \mathrm{~h}$.

Samples were then dried at $60{ }^{\circ} \mathrm{C}$ for two weeks and homogenised again through a $2-\mathrm{mm}$ sieve. Total organic carbon (TOC) and total nitrogen (TN) were analysed by a LECO TruMac Elementar analyser. $\mathrm{pH}$ was analysed in 1:2.5 soil:water ratio (Blakemore et al. 1987) with a Eutech pH $700 \mathrm{pH}$ meter.

Data analysis

The results of the experiment, disregarding the baseline ones, were analysed for each soil depth independently. $\mathrm{pH}, \mathrm{NH}_{4}{ }^{+}-\mathrm{N}$ and $\mathrm{NO}_{3}{ }^{-} \mathrm{N}$ results were analysed with an analysis of covariance with Treatment (mānuka, pasture) and Day as independent variables. The assumptions of normality, homoscedasticity and linearity were assessed by plotting the residuals of the model. TOC, TN, soil moisture and $\mathrm{C}: \mathrm{N}$ ratio did not fulfil the linearity assumptions and were analysed for differences between pasture and mānuka by t-tests for each day, and $E$. coli enumeration, by non-parametric Kruskal-Wallis. Similar to Prosser et al. (2016), linear regression between $\log _{10}(\mathrm{MPN})$ and Day were calculated to estimate decimal $E$. coli reductions in the soil. A correlation matrix between the variables was calculated using the non-parametric Kendall correlation. The analyses were performed with the stats package of the programme R (R Core Team 2018).

\section{Results}

Rainfall, weather conditions, and soil moisture

During the experiment, temperature varied from $9{ }^{\circ} \mathrm{C}$ to $24{ }^{\circ} \mathrm{C}$ (GWRC 2021). As shown in Fig. 3, conditions were relatively dry before baseline sampling (day 0) and soil moisture on Day 0 was not different between the two treatments (Fig. 4). A notable rain event was received during the days of the synthetic excrement application (day A) and the first sampling day (day 1). The next rain event happened after the 


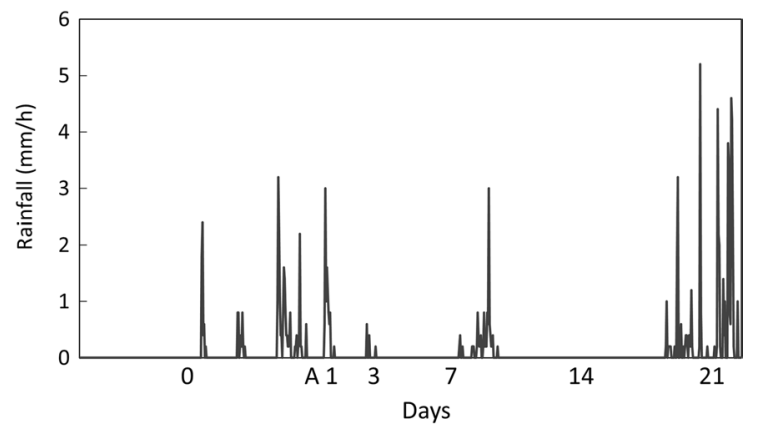

Fig. 3 Hourly rainfall during the experiment. 0: baseline sampling, A: day of "excrement" application, 1 to 21: days of sampling. Data retrieved from weather station Lake Wairarapa at Eastern Lake Shore (GWRC 2021)

seventh day of sampling and again at the end of the experiments. These rainfall conditions were reflected in the soil moisture during the experiment (Fig. 4), with an increase between baseline sampling and the first day of sampling after the excrement application, then a decline back to around baseline levels before a slight increase toward Day 21 (Fig. 4). Differences in soil moisture between treatments were only significant on the topsoil $(0-10 \mathrm{~cm})$ on days 3 and 7, with drier soil under mānuka (Fig. 4).

\section{E. coli}

The application of the synthetic excrement increased the numbers of $E$. coli in the topsoil $(0-10 \mathrm{~cm})$ after the first day from none to an average of $1.5 \times 10^{3}$ MPN $\mathrm{g}^{-1}$ and $2.3 \times 10^{3} \mathrm{MPN} \mathrm{g}^{-1}$ of dry soil under mānuka and pasture, respectively. In both treatments, E. coli slowly decreased over the remainder of the experiment without showing a difference between treatments (Fig. 4). Linear regressions of $\log _{10}(\mathrm{MPN})$ and Day calculated a $90 \%$ reduction (1 $\log _{10}$ reduction) in E. coli in the topsoil on days 9 and 8.5 under mānuka and pasture, respectively. Only one day after the synthetic excrement application, E. coli was already detected in deeper soil below $10 \mathrm{~cm}$ and
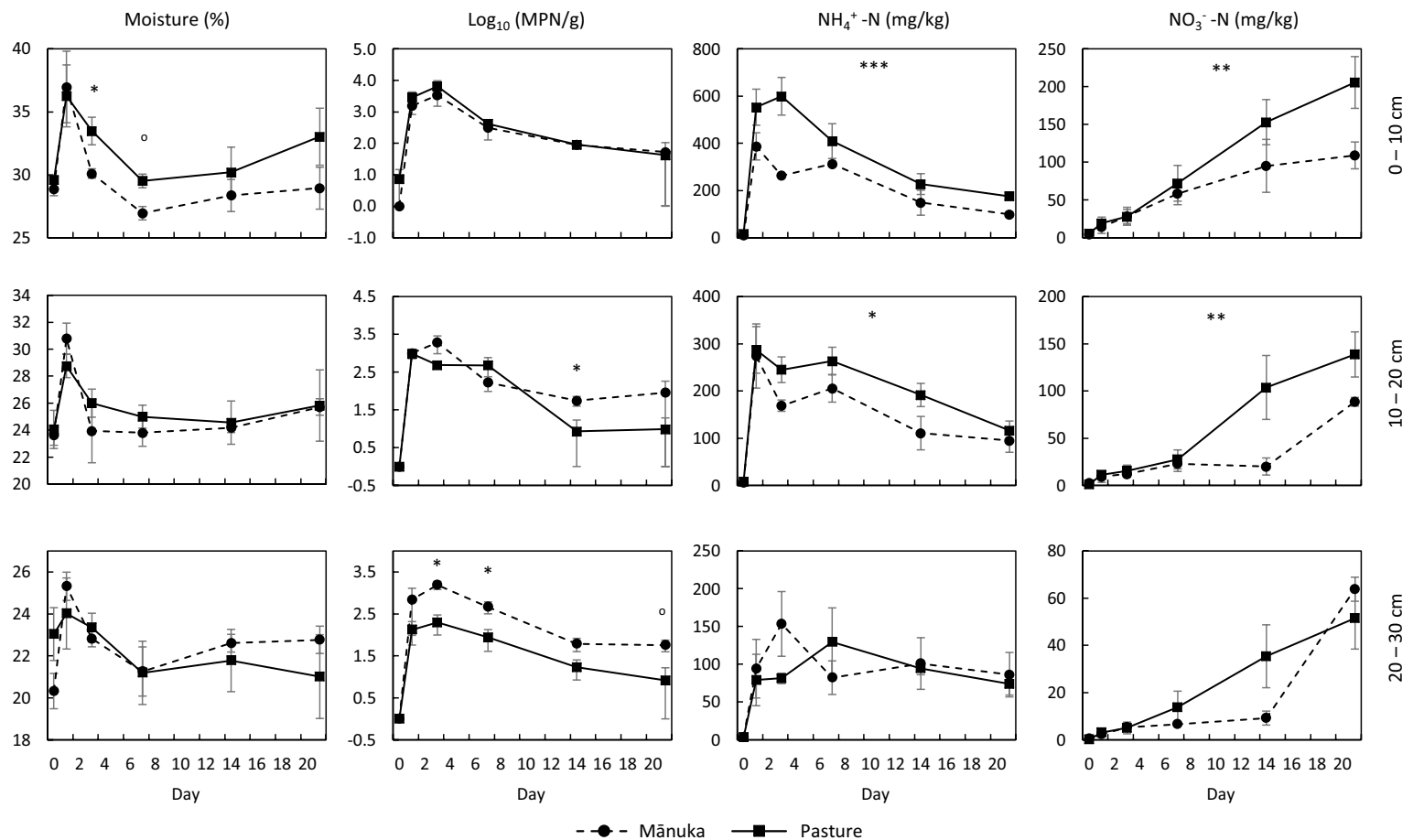

Fig. 4 Changes in soil factors under mānuka and pasture over the length of the experiment. *,**, and $* * *$ in the centre top of the graph indicate significant effect of treatment (mānuka and pasture) over the dependent variable in each soil depth (ANCOVA, $p<0.05, p<0.01$ and $p<0.001$ respectively).

$*,{ }^{\circ}$ in the top of certain days indicate significant differences between treatment on that day (Kruskal-Wallis $p<0.1$ and $\mathrm{p}<0.05$ respectively). Note that day 0 represents results of baseline sampling, which happened one month before the experiment started 
also below $20 \mathrm{~cm}$ (Fig. 4) in both treatments. There were only significant differences between mānuka and pasture in the 10-20 cm soil depth on day 14 and more consistent differences between treatments in the deeper soil at 20-30 cm, with higher E. coli numbers under mānuka than under pasture (Fig. 4). There was no relationship between E. coli numbers and any other soil variable (Kendall correlation $<0.4$ ).

\section{Nitrogen and carbon}

Total organic carbon and total nitrogen significantly increased in the soil after the application of the synthetic excrement (Fig. 5) and showed very little variation along the experiment in the three soil depths. There was no significant difference between mānuka and pasture. The C:N ratio decreased after the synthetic excrement application and did not significantly change along the experiment or between treatments (Fig. 5). Although total nitrogen was not different between mānuka and pasture, there were significant differences between them regarding the evolution of inorganic nitrogen over the experiment. Background concentration of $\mathrm{NH}_{4}^{+}-\mathrm{N}$ in the topsoil was $13 \mathrm{mg} \mathrm{kg}^{-1}$ and was not different between mānuka and pasture. Following a large increase of $\mathrm{NH}_{4}{ }^{+}-\mathrm{N}$ after synthetic excrement application (up to an average of $470 \mathrm{mg} \mathrm{kg}{ }^{-1}$ in the topsoil), $\mathrm{NH}_{4}^{+}$ $-\mathrm{N}$ concentration declined over the course of the experiment at $0-10 \mathrm{~cm}$ and $10-20 \mathrm{~cm}$, with a significant influence by treatment in these two soil depths (Fig. 4 and Table 1). $\mathrm{NH}_{4}{ }^{+}-\mathrm{N}$ at $20-30 \mathrm{~cm}$ was constant during the experiment and without difference between treatments. Background $\mathrm{NO}_{3}{ }^{-}-\mathrm{N}$ concentration in the topsoil was low $\left(4.8 \mathrm{mg} \mathrm{kg}^{-1}\right)$ and similar in the two treatments. $\mathrm{NO}_{3}{ }^{-}-\mathrm{N}$ significantly increased in the topsoil and at $10-20 \mathrm{~cm}$ throughout the experiment with a significantly higher rate in pasture than in mānuka (Fig. 4 and Table 1). At the end of the experiment $\mathrm{NO}_{3}{ }^{-}-\mathrm{N}$ concentrations
TOC (\%)


TN (\%)
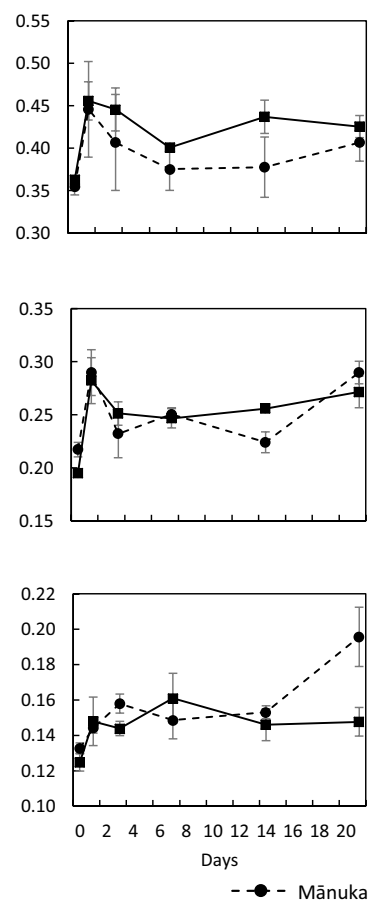

Fig. 5 Changes in soil factors under mānuka and pasture over the length of the experiment. ${ }^{\circ}$ and $* *$, in the centre top of the graph indicate significant effect of treatment (mānuka and pasture) over the dependent variable in each soil depth


(ANCOVA, $\mathrm{p}<0.1$ and $\mathrm{p}<0.01$ respectively). Note that day 0 represents results of baseline sampling, which happened one month before the experiment started 
Table 1 Results of the ANCOVA analysis ( $p$-values) of the results of inorganic nitrogen and $\mathrm{pH}$ in each soil depth

\begin{tabular}{llll}
\hline Variables & $\mathbf{N H}_{\mathbf{4}}{ }^{+}-\mathbf{N}$ & $\mathbf{N O}_{3}{ }^{-}-\mathbf{N}$ & $\mathbf{p H}$ \\
\hline $0-10 \mathrm{~cm}$ & & & \\
Treatment & 0.000 & 0.010 & 0.014 \\
Day & 0.000 & 0.000 & 0.000 \\
Treatment * Day & 0.064 & 0.007 & 0.005 \\
$10-20 \mathrm{~cm}$ & & & \\
Treatment & 0.033 & 0.005 & 0.529 \\
Day & 0.000 & 0.000 & 0.000 \\
Treatment * Day & 0.933 & 0.011 & 0.082 \\
20-30 cm & & & \\
Treatment & 0.543 & 0.402 & 0.169 \\
Day & 0.472 & 0.000 & 0.000 \\
Treatment * Day & 0.683 & 0.835 & 0.540 \\
\hline
\end{tabular}

in the topsoil were $109 \mathrm{mg} \mathrm{kg}^{-1}$ and $205 \mathrm{mg} \mathrm{kg}^{-1}$ under mānuka and pasture, respectively.

\section{Soil pH}

Background soil $\mathrm{pH}$ was different in the soil depths and slightly different between mānuka and pasture $(p=0.06)$. After the application of the synthetic excrement, $\mathrm{pH}$ increased in the topsoil and decreased along the experiment with significant influence by treatment (Fig. 5 and Table 1). At 10-20 cm, the effect of treatment was marginal, and at $20-30 \mathrm{~cm}$, there was no significant effect.

\section{Discussion}

E. coli

In contrast to the results of Prosser et al. (2016) and Gutierrez-Gines et al. (2021), who found a $90 \%$ reduction in $E$. coli counts in 8 and 14 days under mānuka and 93 and 45 days under pasture, respectively, our experiment indicated there were no significant differences between the two plant covers in E. coli reduction in both, the topsoil and $10-20 \mathrm{~cm}$. E. coli survival and mortality rates in the soil can be influenced by a multitude of factors including physical and chemical soil properties (e.g. water availability, $\mathrm{pH}$ ), atmospheric conditions (e.g. temperature), and interactions between other organisms within soils (e.g. indigenous microflora) (van Elsas et al. 2011). Avery et al. (2004) showed a rapid decrease of E. coli in soil after organic waste application (over $1 \log _{10}$ decrease after one day, and about $2 \log _{10}$ after two days). Our results, however, are more similar to studies showing stable numbers for the first few days (Mubiru et al. 2000; Nicholson et al. 2005; Ogden et al. 2001), followed by a decrease which became slower with time, resulting in E. coli survival in the soil for 1-2 months depending on the climate and soil conditions (Avery et al. 2004; Horswell et al. 2007; Nicholson et al. 2005). The addition of organic carbon and nitrogen in the form of urea at the same time than the addition of $E$. coli, might have promoted the survival, or even re-growth, of this bacterium in the soil. In fact, Jamieson et al. (2002) and Horswell et al. (2010) showed that organic matter and nutrients are key factors for the survival of enteric bacterial in the soil. These factors demonstrate to be more important than root systems for the survival of $E$. coli in field conditions.

While E. coli reductions exist in all horizons, a rapid reduction in the $0-10 \mathrm{~cm}$ horizon and more gradual reductions in the $10-20$ and $20-30 \mathrm{~cm}$ horizons, as well as the presence of $E$. coli in the 20-30 cm soil depth one day after the "excrement" application, could suggest E. coli movement down the soil profile was enhanced by rainfall during the first two days of the experiment. Gagliardi and Karns (2000) detected E. coli in leachates from lysimeters treated with $E$. coli-inoculated manure at the same levels as the inoculum for $8 \mathrm{~h}$ after steady rainfall $\left(16.5 \mathrm{~mm} \mathrm{~h}^{-1}\right)$. Moreover, higher E. coli counts in the mānuka treatment in the $20-30 \mathrm{~cm}$ horizon compared with pasture suggests preferential flow enhanced by pivoting mānuka roots, compared with the dense root system of pasture in the topsoil, as demonstrated also by Mishra (2018). Monitoring over a longer period would have given insights of the survival of $E$. coli under these conditions of soil moisture and nutrients, and in the different soil depths, above all if nutrients decreased over time. This is a limitation of the study, which will have to be addressed in further research.

\section{Nitrogen}

Significantly lower concentrations of $\mathrm{NO}_{3}{ }^{-}-\mathrm{N}$ in soil under mānuka compared to pasture supports the hypothesis that mānuka roots can inhibit nitrification 
of $\mathrm{NH}_{4}{ }^{+}$to $\mathrm{NO}_{3}{ }^{-}$in soil. This corroborates the findings of Esperschuetz et al. (2017) who suggested that antimicrobial properties of mānuka roots may reduce the nitrifier bacteria populations in the soil, thus inhibit nitrification and the conversion from $\mathrm{NH}_{4}{ }^{+}$to $\mathrm{NO}_{3}^{-}$.

However, lower $\mathrm{NO}_{3}{ }^{-}-\mathrm{N}$ concentrations could also be attributed to the lower initial concentrations of $\mathrm{NH}_{4}{ }^{+}-\mathrm{N}$ seen in the mānuka treatment, which indicates that there was less $\mathrm{NH}_{4}{ }^{+}$available to transform into $\mathrm{NO}_{3}{ }^{-}$. The elevated $\mathrm{NH}_{4}{ }^{+}-\mathrm{N}$ concentrations in the pasture compared with mānuka was an unanticipated result, as Esperschuetz et al. (2017) attributed the higher concentration of $\mathrm{NH}_{4}{ }^{+}$under mānuka - in comparison to pine - to soil accumulation due to the lower nitrification rate in mānuka root systems.

Studies looking at the application of synthetic urinary nitrogen $(15 \mathrm{~N})$ by Clough et al. (1998) and Frase et al. (1994) found that plant uptake over one year was responsible for $43 \%$ and $21.6-31.4 \%$ of nitrogen reductions, respectively. Similarly, total nitrogen uptake to plant biomass was significantly greater under mānuka than pine (Esperschuetz et al. 2017), although no significant differences in total nitrogen in the soil were observed in that study. In our study, $\mathrm{N}$ plant uptake could only partially explain the large difference between $\mathrm{NH}_{4}{ }^{+}$in mānuka and pasture on day 1 to 7. Assuming that the whole difference in $\mathrm{NH}_{4}{ }^{+}-\mathrm{N}$ between mānuka and pasture $\left(150 \mathrm{mg} \mathrm{kg}{ }^{-1}\right.$ on day 1 and $300 \mathrm{mg} \mathrm{kg}^{-1}$ on day 3) was due to plant uptake as well as luxury uptake of $\mathrm{N}$ by mānuka (Franklin et al. 2015), this species should have produced over $450 \mathrm{~g}$ more fresh weight than pasture in four days, which is unrealistic.

One unknown of the experiment is how ammonium volatilisation contributed to the differences in ammonium observed between the two treatments. Decau et al. (2003) concluded that around 12-25\% of urinary nitrogen can be lost through ammonium volatilisation. Elevated soil moisture conditions observed in our study, as well as similar moisture under mānuka and pasture, suggests, however, that this is unlikely. Clough et al. (2003) suggested that urease enzymes rapidly hydrolyse urea to ammonium in moist soil conditions. Similarly, $10 \mathrm{~mm}$ of rainfall following application of synthetic urinary nitrogen was found to minimise excessive loss via volatilisation (Clough et al. 1998).
In addition to BNI, another potential contributor to nitrogen cycling in this experiment could be the inhibition of urease activity via the mānuka root networks. The use of synthetic urease inhibitors has been shown to reduce nitrogen losses through ammonium volatilisation and leachate following urea application (Gioacchini et al. 2002).

We cannot discard the possibility of losing $\mathrm{N}$ via preferential flow created by mānuka root systems, as it was discussed previously for E. coli. However, in contrast to $E$. coli results, there was no difference in inorganic nitrogen in the $20-30 \mathrm{~cm}$ depth between the two plants. It could be expected that if the differences in inorganic nitrogen between mānuka and pasture were due to $\mathrm{N}$ losses by plant uptake, ammonia volatilisation or leaching via preferential flow, there would be a different nitrogen concentration in the soil. However, total nitrogen and $\mathrm{C}: \mathrm{N}$ ratio were not significantly different between the two plant types, which could imply that differences were mostly due to speciation (rather than losses), or that the differences in inorganic nitrogen were too small compared with the total nitrogen concentration, which would make the comparison difficult.

Wider implications and future directions

This study indicates that mānuka has a limited impact on reducing common agricultural pollutants (with a greater impact on nitrogen than E. coli) when compared to pasture from grazing riparian areas. Challenges were expected in attempting this study in a 'real-world' setting. However, the results - particularly for inorganic nitrogen - are promising. The elevated values of nitrate and ammonium under pasture are interesting and suggest a higher potential for nitrate leaching. However, further longitudinal studies with older mānuka stands, over different seasons, and including the quantification of nitrogen losses such as ammonia volatilisation and nitrogen leaching, are required to assess the validity of the results presented here, contributing to our understanding of the role mānuka plays in pollutant mitigation.

Agricultural catchments are considered responsible for the sharp rise of nitrate in surface water and groundwater systems, mainly from urine in grazed paddocks (Di and Cameron 2002). However, many of the proposed solutions to minimising losses involve lost production costs or are time intensive (de Klein 
2001; Di and Cameron 2002). While planting mānuka would not be without costs (e.g. initial planting and maintenance during establishment), it is much less time intensive and would not involve major changes to on-farm practices. Depending on climate and land conditions, there is potential economic incentive through mānuka honey and oil production. The mānuka honey industry in particular is increasingly economically important, with a $35 \%$ increase in total honey exports from 2015 to 2016, fetching around 12-148 NZD kg-1 (MPI 2017). Similarly, mānuka essential oil production could benefit from the high fertility farm soils, with potential gross values of US\$ 26,000 ha ${ }^{-1}$ (Seyedalikhani et al. 2019). These alternative mānuka uses would not only mitigate the effect of farming activities on water quality but diversify the farm incomes.

Although the use of plants with antimicrobial properties to reduce the migration of $\mathrm{N}$ and pathogens from farming areas into water bodies is still an incipient research line (Gutierrez-Gines et al. 2021), there is a wide opportunity worldwide given the large range of plant species with antibacterial activity being investigated (Chassagne et al. 2021). According to those authors, Lamiaceae, Fabaceae and Asteraceae are the families with the greatest number of species with known antimicrobial properties. These families present a wide distribution around the world, and most of them could potentially be a source of income for farmers with similar uses than those described for mānuka (i.e. Nieto 2017).

Acknowledgements Planting of mānuka trees and site maintenance was supported by Greater Wellington Regional Council and local Māori indigenous community Ngāti Kahungunu ki Wairarapa. Thank you to Paul Smith, landowner of the Hinaburn Station, for access to his property to run this experiment. Statistical advice was provided by David Wood from the Institute of Environmental Science and Research. Dr. Brett Robinson and Dr. Kristin Bohm peer-reviewed this manuscript prior to submission.

Funding This project was funded by the Centre for Integrated Biowaste Research, under The Institute of Environmental Science and Research Strategic Science Investment Fund from the Ministry of Business, Innovation and Employment, New Zealand (C03X1701). Further financial support was provided by Victoria University of Wellington.

Data availability The datasets generated during and/or analysed during the current study are available from the corresponding author on reasonable request.

\section{Declarations}

Conflict of interest The authors have no conflicts of interest to declare that are relevant to the content of this article.

Open Access This article is licensed under a Creative Commons Attribution 4.0 International License, which permits use, sharing, adaptation, distribution and reproduction in any medium or format, as long as you give appropriate credit to the original author(s) and the source, provide a link to the Creative Commons licence, and indicate if changes were made. The images or other third party material in this article are included in the article's Creative Commons licence, unless indicated otherwise in a credit line to the material. If material is not included in the article's Creative Commons licence and your intended use is not permitted by statutory regulation or exceeds the permitted use, you will need to obtain permission directly from the copyright holder. To view a copy of this licence, visit http://creativecommons.org/licenses/by/4.0/.

\section{References}

Avery LM, Hill P, Killham K, Jones DL (2004) Escherichia coli O157 survival following the surface and subsurface application of human pathogen contaminated organic waste to soil. Soil Biol Biochem 36:2101-2103. https://doi.org/10.1016/j.soilbio.2004.05.018

Bain R, Cronk R, Hossain R, Bonjour S, Onda K, Wright J, Yang H, Slaymaker T, Hunter P, Prüss-Ustün A, Bartram J (2014) Global assessment of exposure to faecal contamination through drinking water based on a systematic review. Trop Med Int Health 19(8):917-927. https://doi.org/10.1111/tmi.12334

Billen G, Garnier J, Lassaletta L (2013) The nitrogen cascade from agricultural soils to the sea: modelling nitrogen transfers at regional watershed and global scales. Philos Trans R Soc B 368:20130123. https://doi.org/10.1098/ rstb.2013.0123

Blakemore LC, Searle PL, Daly BK (1987) Methods for chemical analysis of soils. NZ Soil Bureau Scientific Report 80

Chassagne F, Samarakoon T, Porras G, Lyles JT, Dettweiler M, Marquez L, Salam AM, Shabih S, Farrokhi DR, Quave CL (2021) A systematic review of plants with antibacterial activities: a taxonomic and phylogenetic perspective. Front Pharmacol 11:2069. https://doi.org/ 10.3389/fphar.2020.586548

Clough TJ, Ledgard SF, Sprosen MS, Kear MJ (1998) Fate of $15 \mathrm{~N}$ labelled urine on four soil types. Plant Soil 199:195203. https://doi.org/10.1023/A:1004361009708

Clough TJ, Sherlock RR, Mautner MN, Milligan DB, Wilson PF, Freeman CG, McEwan MJ (2003) Emission of nitrogen oxides and ammonia from varying rates of applied synthetic urine and correlations with soil chemistry. Soil Research 41:421-438. https://doi.org/10.1071/SR02105

Collins R, McLeod M, Hedley M, Donnison A, Close M, Hanly J, Horne D, Ross C, Davies-Colley R, Bagshaw C, Matthews L (2007) Best management practices to 
mitigate faecal contamination by livestock of New Zealand waters. N Z J Agric Res 50:267-278. https://doi. org/10.1080/00288230709510294

Core Team R (2018) R: a language and environment for statistical computing. R Foundation for Statistical Computing, Vienna

de Klein CAM (2001) An analysis of environmental and economic implications of nil and restricted grazing systems designed to reduce nitrate leaching from New Zealand dairy farms. II. Pasture production and cost/benefit analysis. N Z J Agric Res 44:217-235. https://doi.org/10. 1080/00288233.2001.9513479

Decau ML, Simon JC, Jacquet A (2003) Fate of urine nitrogen in three soils throughout a grazing season. J Environ Qual 32:1405-1413. https://doi.org/10.2134/jeq2003.1405

Di HJ, Cameron KC (2002) Nitrate leaching in temperate agroecosystems: sources, factors and mitigating strategies. Nutr Cycl Agroecosyst 64:237-256. https://doi. org/10.1023/A:1021471531188

Downward RL (2013) Nitrification inhibition by common plants in New Zealand's agricultural landscapes. Lincoln University, Lincoln

Dymond JR, Ausseil AG, Parfitt RL, Herzig A, McDowell RW (2013) Nitrate and phosphorus leaching in New Zealand: a national perspective. N Z J Agric Res 56:4959. https://doi.org/10.1080/00288233.2012.747185

Esperschuetz J, Balaine N, Clough TJ, Bulman S, Dickinson NM, Horswell J, Robinson BH (2017) The potential of L. scoparium, K. robusta and P. radiata to mitigate N-losses in silvopastural systems. Environ Pollut 225:12-19. https://doi.org/10.1016/j.envpol.2017.03. 042

Franklin HM, Dickinson NM, Esnault CJD, Robinson BH (2015) Native plants and nitrogen in agricultural landscapes of New Zealand. Plant Soil 394:407-420. https:// doi.org/10.1007/s11104-015-2622-2

Frase PM, Cameron KC, Sherlock RR (1994) Lysimeter study of the fate of nitrogen in animal urine returns to irrigated pasture. Eur J Soil Sci 45:439-447. https://doi.org/10. 1111/j.1365-2389.1994.tb00529.x

Gagliardi JV, Karns JS (2000) Leaching of Escherichia coli O157:H7 in diverse soils under various agricultural management practices. Appl Environ Microbiol 66:877-883. https://doi.org/10.1128/aem.66.3.877-883.2000

Galloway JN, Aber JD, Erisman JW, Seitzinger SP, Howarth RW, Cowling EB, Cosby BJ (2003) The nitrogen Cascade. BioScience 53:341-356. https://doi.org/10.1641/00063568(2003)053[0341:TNC]2.0.CO;2

Gioacchini P, Nastri A, Marzadori C, Giovannini C, Vittori Antisari L, Gessa C (2002) Influence of urease and nitrification inhibitors on $\mathrm{N}$ losses from soils fertilized with urea. Biol Fertil Soils 36:129-135. https://doi.org/10. 1007/s00374-002-0521-1

Gutierrez-Gines MJ, Alizadeh $\mathrm{H}$, Alderton E, Ambrose V, Meister A, Robinson BH, Halford S, Prosser JA, Horswell J (2021) Phytoremediation of microbial contamination in soil by New Zealand native plants. Appl Soil Ecol 176:104040. https://doi.org/10.1016/j.apsoil.2021.104040

GWRC (2021) Environmental monitoring \& research. In: GWR council (ed), Wellington
Horswell J, Ambrose V, Clucas L, Leckie A, Clinton P, Speir TW (2007) Survival of Escherichia coli and Salmonella spp. after application of sewage sludge to a Pinus radiata forest. J Appl Microbiol 103:1321-1331. https://doi.org/ 10.1111/j.1365-2672.2007.03373.x

Horswell J, Hewitt J, Prosser J, Van Schaik A, Croucher D, Macdonald C, Burford P, Susarla P, Bickers P, Speir T (2010) Mobility and survival of Salmonella typhimurium and human adenovirus from spiked sewage sludge applied to soil columns. J Appl Microbiol 108:104-114. https:// doi.org/10.1111/j.1365-2672.2009.04416.x

Houlbrooke DJ, Horne DJ, Hedley MJ, Hanly JA, Snow VO (2004) A review of literature on the land treatment of farm-dairy effluent in New Zealand and its impact on water quality. N Z J Agric Res 47:499-511. https://doi. org/10.1080/00288233.2004.9513617

Jamieson RC, Gordon RJ, Sharples KE, Stratton GW, Madani A (2002) Movement and persistence of fecal bacteria in agricultural soils and subsurface drainage water: a review. Can Biosyst Eng 44:1.1-1.9

Julian JP, de Beurs KM, Owsley B, Davies-Colley RJ, Ausseil AGE (2017) River water quality changes in New Zealand over 26 years: response to land use intensity. Hydrol Earth Syst Sci 21:1149-1171. https://doi.org/10.5194/ hess-21-1149-2017

Kormanovskii LP, Tekuchev IK, Tekucheva MS, Chernovol YN (2017) Scientific justification for determination of the daily output of cow excrement. Russ Agric Sci 43:53-56. https://doi.org/10.3103/S1068367417010128

LandcareResearch (2018) New Zealand soil Classifiation. Manaaki Whenua - Landcare Research New Zealand Ltd., Lincoln

Lee WG, Meurk CD, Clarkson BD (2008) Agricultural intensification: whither indigenous biodiversity? N Z J Agric Res 51:457-460. https://doi.org/10.1080/00288230809510475

MacLeod CJ, Moller H (2006) Intensification and diversification of New Zealand agriculture since 1960: an evaluation of current indicators of land use change. Agric Ecosyst Environ 115:201-218. https://doi.org/10.1016/j.agee. 2006.01.003

McDowell RW, Stevens DR, Cave V, Paton RJ, Johnson M (2006) Effects of shelter belts on fence-line pacing of deer and associated impacts on water and soil quality. Soil Use Manag 22:158-164. https://doi.org/10.1111/j.1475-2743. 2006.00024.x

McKergow LA, Matheson FE, Quinn JM (2016) Riparian management: a restoration tool for New Zealand streams. Ecological Management \& Restoration 17:218-227. https:// doi.org/10.1111/emr.12232

Ministry for the Environment, StatsNZ (2018) New Zealand's Environmental Reporting Series: Our land 2018

Mishra M (2018) Interactions between Escherichia coli and the New Zealand native plants Leptospermum scoparium and Kunzea robusta. Lincoln Univeristy, Lincoln

Moriarty EM, Sinton LW, Mackenzie ML, Karki N, Wood DR (2008) A survey of enteric bacteria and protozoans in fresh bovine faeces on New Zealand dairy farms. J Appl Microbiol 105:2015-2025. https://doi.org/10.1111/j.13652672.2008.03939.x 
MPI (2017) Apiculture. Ministry for Primary Industries 2016 apiculture monitoring programme. Ministry for Primary Industries, Wellington

Mubiru DN, Coyne MS, Grove JH (2000) Mortality of Escherichia coli $\mathrm{O} 157: \mathrm{H7}$ in two soils with different physical and chemical properties. J Environ Qual 29:1821-1825. https://doi.org/10.2134/jeq2000.004724250029000 $60012 x$

Nicholson FA, Groves SJ, Chambers BJ (2005) Pathogen survival during livestock manure storage and following land application. Bioresour Technol 96:135-143. https://doi. org/10.1016/j.biortech.2004.02.030

Nieto G (2017) Biological activities of three essential oils of the Lamiaceae Family. Medicines 4:63. https://doi.org/10. 3390/medicines4030063

Ogden ID, Fenlon DR, Vinten AJA, Lewis D (2001) The fate of Escherichia coli $\mathrm{O} 157$ in soil and its potential to contaminate drinking water. Int J Food Microbiol 66:111117. https://doi.org/10.1016/S0168-1605(00)00508-0

Pandey PK, Kass PH, Soupir ML, Biswas S, Singh VP (2014) Contamination of water resources by pathogenic bacteria. AMB Express 4:51. https://doi.org/10.1186/ s13568-014-0051-X

Parfitt RL, Schipper LA, Baisden WT, Elliott AH (2006) Nitrogen inputs and outputs for New Zealand in 2001 at national and regional scales. Biogeochemistry 80:71-88. https://doi.org/10.1007/s10533-006-0002-y

Prosser JA, Anderson CWN, Horswell J, Speir TW (2014) Can manuka (Leptospermum scoparium) antimicrobial properties be utilised in the remediation of pathogen contaminated land? Soil Biol Biochem 75:167-174. https://doi. org/10.1016/j.soilbio.2014.04.003

Prosser JA, Woods RR, Horswell J, Robinson BH (2016) The potential in-situ antimicrobial ability of Myrtaceae plant species on pathogens in soil. Soil Biol Biochem 96:1-3

Ryszkowski L, Kędziora A (2007) Modification of water flows and nitrogen fluxes by shelterbelts. Ecol Eng 29:388-400. https://doi.org/10.1016/j.ecoleng.2006.09.023
Scheile T, Isselstein J, Tonn B (2018) Herbage biomass and uptake under low-input grazing as affected by cattle and sheep excrement patches. Nutr Cycl Agroecosyst 112:277-289. https://doi.org/10.1007/s10705-018-9945-3

Selbie DR, Buckthought LE, Shepherd MA (2015) Chapter four - the challenge of the urine patch for managing nitrogen in grazed pasture systems. In: Sparks DL (ed) Advances in agronomy. Academic Press, Cambridge

Seyedalikhani S, Esperschuetz J, Dickinson NM, Hofmann R, Breitmeyer J, Horswell J, Robinson BH (2019) Biowastes to augment the essential oil production of Leptospermum scoparium and Kunzea robusta in low-fertility soil. Plant Physiol Biochem 137:213-221. https://doi.org/10.1016/j. plaphy.2019.02.008

Stephens JMC, Molan PC, Clarkson BD (2005) A review of Leptospermum scoparium (Myrtaceae) in New Zealand. N Z J Bot 43:431-449. https://doi.org/10.1080/0028825X. 2005.9512966

Subbarao GV, Ito O, Sahrawat KL, Berry WL, Nakahara K, Ishikawa T, Watanabe T, Suenaga K, Rondon M, Rao IM (2006) Scope and strategies for regulation of nitrification in agricultural systems-challenges and opportunities. Crit Rev Plant Sci 25:303-335. https://doi.org/10.1080/ 07352680600794232

van Elsas JD, Semenov AV, Costa R, Trevors JT (2011) Survival of Escherichia coli in the environment: fundamental and public health aspects. ISME J 5:173-183. https://doi. org/10.1038/ismej.2010.80

Williams PME (1996) Te rongoā Māori: Maori medicine. Reed, Auckland

Publisher's note Springer Nature remains neutral with regard to jurisdictional claims in published maps and institutional affiliations. 